\title{
PERANCANGAN LEMBAR KEGIATAN PESERTA DIDIK (LKPD) BERBASIS PEMBELAJARAN INKUIRI TERBIMBING (GUIDED INQUIRY LEARNING) PADA MATERI SISTEM EKSKRESI
}

\author{
Nur Leli ${ }^{1 *}$, Mariaty Sipayung ${ }^{1}$ \\ ${ }^{I}$ Program Studi Pendidikan Biologi, Fakultas Matematika dan Ilmu Pengetahuan Alam, Universitas Negeri Medan, \\ Jalan Willem Iskandar Pasar V Medan Estate 20221, Sumatera Utara, Indonesia
}

Korespondensi Author: nurleli3497@gmail.com (Leli)

\section{INFO ARTIKEL}

\section{Histori Artikel}

Received 24 Agustus 2018

Revised 13 Januari 2019

Accepted 15 Maret 2019

Published 7 Juli 2019

Keywords:

Designing worksheet, Guided Inquiry Learning, Excretory System

\begin{abstract}
The aim of this research are firstly to know the feasibility level of excretory system worksheet through guided inquiry learning based on the assessment of material lecturer expert, leaning lecturer expert,biology teachers and students, secondly to know the ability thinking critically and through classical student learning for $11^{\text {th }}$ grade MAN 1 Medan 2017/2018. This research belongs to research and development (R\&D), research study which focused on 4-D. Subject of this research were material lecturer expert, leaning lecturer expert, 3 biology teachers, 20 students (small group testing) and 37 students (restricted field disseminate). The object of this study was material of excretory system. The instruments of this research were validity sheet and questionnaire. The Result of this research showed assessment percentages; 91,8\% (very appropriate) from lecturer of material expert,93,75(very appropriate) from lecturer of learning expert, 87,56 \% (very appropriate) response of biology teacher and the last $76,47 \%$ (good) from response of students in small group testing. The result of the average percentage of students critical thinking ability in the limited field test is $67.33 \%$ (good enough) and the students learning completeness is achieved by $86.11 \%$.
\end{abstract}

\section{How to Cite:}

Leli, N. \& Sipayung, M. (2019). Perancangan Lembar Kegiatan Peserta Didik (LKPD) Berbasis Pembelajaran Inkuiri Terbimbing (Guided Inquiry Learning) Pada Materi Sistem Ekskresi. Jurnal Pelita Pendidikan, 7(1), 001-008.

\section{PENDAHULUAN}

Proses pembelajaran pada kurikulum 2013 untuk semua jenjang dilaksanakan menggunakan pendekatan saintifik (Scientific Approach) melalui kegiatan mengamati, menanya, mencoba/ mengumpulkan informasi, mengasosiasi dan mengkomunikasikan (Permendikbud No. 65 Tahun 2013). Dalam pendekatan saintifik, siswa dituntut membangun pengetahuan yang dimiliki melalui metode ilmiah. Oleh karena itu siswa dipandang sebagai subjek belajar bukan lagi objek belajar sehingga dituntut secara aktif dalam pembelajaran.

Fadillah, dkk (2015) mengatakan bahwa penguatan pendekatan saintifik perlu diterapkan dengan pembelajaran berbasis penyingkapan/penyelidikan (inquiry learning). Pembelajaran inkuiri menekankan pada aktivitas, 
keterampilan, serta pengetahuan melalui pencarian aktif berdasarkan rasa keingintahuan.

Hadiati dan Yusuf (2016) menyatakan bahwa pembelajaran inkuiri (inquiry learning) cocok digunakan untuk pembelajaran IPA khususnya biologi dimana siswa terlibat langsung dengan objek yang dipelajarinya. Kegiatan pembelajaran berbasis inquiry merupakan wujud nyata dari student centered learning yang implementasinya untuk meningkatkan keterampilan dasar sekaligus meningkatkan kemampuan kognitif dan mengembangkan sikap ilmiah siswa.

Selain model pembelajaran, guru juga memerlukan suatu bahan ajar yang sesuai dengan kurikulum 2013. Salah satu bahan ajar yang yang mendukung proses pembelajaran siswa adalah Lembar Kegiatan Peserta Didik (LKPD). Kegiatan pembelajaran yang dibekali dengan perangkat Lembar Kegiatan Peserta Didik (LKPD) mendukung sepenuhnya keterlibatan siswa dalam pembelajaran pengalaman langsung. Pernyataan tersebut didukung oleh Rehulina (2015) yang menyatakan bahwa untuk mendukung kegiatan pembelajaran diperlukan adanya satu panduan yang terarah yaitu Lembar Kegiatan Peserta Didik (LKPD).

LKPD disusun menggunakan beberapa kriteria yang tujuannya yaitu untuk menarik siswa agar lebih aktif dalam proses pembelajaran. Namun, dalam penerapannya guru belum mampu menyediakan LKPD sesuai dengan kebutuhan pembelajaran sesuai dengan tuntutan kurikulum 2013 khususnya berbasis penyelidikan (inquiry).

Studi pendahuluan menunjukkan bahwa LKPD yang beredar masih beragam kualitasnya, salah satunya LKPD tersebut kurang mengembangkan pengetahuan siswa dalam pembelajaran secara ilmiah. Siswa hanya berfokus pada penugasan materi yang ada pada LKPD tanpa melakukan proses penyelidikan yang akan membangun konsep mereka dalam pembelajaran pengalaman langsung.

Hasil penelitian lain menyatakan bahwa LKPD yang digunakan siswa SMA/MA belum sesuai dengan pengertian LKPD sesungguhnya, LKPD yang digunakan belum mendorong siswa untuk belajar bermakna dan menemukan konsep yang benar, LKPD ini berisi kumpulan-kumpulan soal yang kemudian dijadikan guru sebagai tugas/pekerjaan rumah bagi siswa, siswa hanya dituntut mengerjakan soal-soal latihan yang ada dalam LKPD tanpa memahami materi terlebih dahulu (Sari dan Lepiyanto, 2016).

Berdasarkan observasi yang dilakukan di MAN 1 Medan, diketahui bahwa guru Biologi belum menyediakan LKPD sesuai dengan kebutuhan pembelajaran kurikulum 2013 khususnya berbasis penyelidikan (inquiry). Guru hanya memberikan latihan soal disetiap akhir pembelajaran sebagai bahan evaluasi. Selain itu, dalam pembelajarannya guru menggunakan metode pengajaran dengan cara presentasi, siswa tidak diarahkan untuk melakukan eksperimen atau penyelidikan guna mengembangkan konsep yang dimiliki siswa.

Ketersediaan LKPD berbasis guided inquiry menjadi alternatif pembelajaran yang cocok diterapkan untuk melatih siswa bekerja secara ilmiah dalam mengembangkan keterampilan sains dan kemampuan berfikir siswa.Wahyuningsih, dkk (2014) dalam hasil penelitiannya menyatakan bahwa hasil penilaian ahli materi dan ahli media menunjukkan bahwa LKPD layak untuk digunakan. Selain itu, keterlaksanaan tahapan inkuiri terbimbing baik pada aktivitas guru dan siswa termasuk kategori sangat baik, angket respon siswa juga sangat baik pada uji lapangan. Suchman (2012) dalam Fadilah, dkk (2015) juga menyatakan bahwa pembelajaran inkuiri akan lebih memacu keingintahuan siswa tentang proses penyelidikannya dan belajar prosedur ilmiah secara langsung. Pembelajaran inkuiri ini juga dapat diintegrasikan ke dalam beberapa model pembelajaran, karena fakta, konsep dan generalisasi yang dapat melatih siswa untuk mengembangkan berfikir kritis. Berdasarkan latar belakang permasalahan diatas, maka dilakukan penelitian ini.

\section{METODE PENELITIAN}

Pelaksanaan uji coba untuk menilai kelayakan produk perancangan LKPD yang dihasilkan di MAN 1 Medan. Pelaksanaan penelitian dimulai sejak bulan April-Juni 2018. Subjek dalam penelitian ini yaitu 1 dosen ahli materi, 1 dosen ahli pembelajaran, 3 guru Biologi, 20 siswa (uji kelompok kecil) serta 36 siswa (uji lapangan terbatas). Objek dalam penelitian ini adalah materi 
Biologi SMA Kelas XI yang terkait dengan KD 3.9 dan KD 4.9.

Jenis penelitian ini adalah penelitian dan pengembangan (Research and development) dengan merancang Lembar Kegiatan Peserta Didik (LKPD) berbasis pembelajaran inkuiri terbimbing (guided inquiry learning) pada materi sistem ekskresi kelas XI SMA/MA. Penelitian dan pengembangan sebagai suatu proses untuk merancang dan memvalidasi produk-produk yang akan digunakan dalam pendidikan dan pembelajaran. Penelitian pengembangan LKPD ini dilakukan berdasarkan analisis kebutuhan dengan mengacu pada kurikulum 2013.

Model pengembangan yang digunakan mengacu pada model 4-D oleh Thiagarajan, S., Semmel, D., \& Semmel, M. (1974). Model pengembangan ini terdiri dari 4 tahap, yaitu: pendefenisian (define), perancangan (design), pengembangan (develop), dan penyebaran (disseminate) (Trianto, 2010). Dari keempat langkah pengembangan tersebut, dalam perancangan LKPD berbasis pembelajaran inkuiri terbimbing, pada tahap disseminate peneliti hanya membatasi penyebaran sampai lapangan terbatas dikarenakan keterbatasan biaya dan waktu. Tahap pendefinisian (Define), tahap pendefinisian bertujuan untuk menetaokan dan mendefinisikan syarat-syarat pembelajaran. Pada tahap ini tindakan yang dilakukan adalah: (1) Analisis ujung depan, meliputi: Analisis kurikulum, analisis kebutuhan dan analisis masalah yang menjadi dasar perancangan LKPD; (2) Analisis siswa, bertujuan untuk menelaah karakter siswa; (3) Analisis konsep, bertujuan untuk mengidentifikasi, merinci dan menyusun secara sistematis konsepkonsep pada LKPD yang akan dirancang; (4) Spesifikasi tujuan pembelajaran, bertujuan untuk menentukan indikator pembelajaran dan penyusunan kajian apa saja yang akan ditampilkan dalam LKPD. Tahap perancangan (Design), tahap perancangan bertujuan untuk menghasilkan prototype LKPD. Pada tahap ini tindakan yang dilakukan meliputi: (1) Penyusunan tes acuan patokan yang disusun berdasarkan hasil perumusan tujuan pembelajaran; (2) Pemilihan media; (3) Pemilihan format LKPD; (4) Membagi struktur LKPD menjadi tiga bagian, yaitu bagian pendahuluan, bagian isi, dan bagian penutup.
Tahap pengembangan (Develop), tahap pengembangan bertujuan untuk menghasilkan draft 1 LKPD berbasis pembelajaran inkuiri terbimbing (guided inquiry learning) yang telah validasi dan direvisi berdasarkan saran yang diberikan oleh validator (dosen ahli), validator yang akan menilai protoype meliputi dosen ahli materi dan dosen ahli pembelajaran yang berasal dari Universitas Negeri Medan. Setelah selesai dinilai oleh dosen ahli, selanjutnya prototype juga akan dinilai oleh 3 guru Biologi MAN 1 Medan. Kemudian diadakan perbaikan dari hasil data yang diperoleh. Selanjutnya adalah uji coba draft 1 yang sudah diperbaiki, bertujuan untuk mengetahui respon siswa. Uji ini dilakukan melalui uji kelompok kecil terhadap 20 siswa. Tahap penyebaran (Disseminate), tahap penyebaran dilakukan secara terbatas dengan melakukan uji lapangan terbatas yang bertujuan untuk mengetahui kemampuan berfikir kritis siswa dan ketuntasan belajar siswa secara klasikal. Uji lapangan terbatas dilakukan dengan memberikan LKPD berbasis inkuiri terbimbing kepada 1 kelas yang terdiri dari 36 orang siswa dan mengarahkan mereka untuk mengerjakan LKPD tersebut secara berkelompok. Berikut skema dan prosedur penelitian yang akan dilakukan, dalam Gambar 1.

Penelitian ini menggunakan instrumen berupa lembar validasi dan angket. Lembar validasi ini nantinya akan diisi oleh dosen ahli materi dan dosen ahli pembelajaran, sedangkan angket akan diisi oleh guru Biologi dan siswa MAN 1 Medan.

Penilaian produk Lembar Kegiatan Peserta Didik (LKPD) oleh ahli materi, ahli pembelajaran, dan guru biologi berupa data deskriptif. Analisis data hasil validasi para ahli dan penilaian guru biologi dilakukan dengan menggunakan skala Likert dengan skala 1 sampai 5 . Dalam perhitungan ini, menggunakan formula sebagai berikut:

$$
P=\frac{\sum}{N} \times 100 \%
$$

Keterangan:

$\mathrm{P}=$ Persentase kategori

$\sum=$ Jumlah skor jawaban kategori yang dipilih $\mathrm{N}=$ Total skor ideal

(Sudijono, 2012). 
Sementara untuk analisis hasil penilaian siswa dilakukan dengan menggunakan skala Guttman dengan skala 1 dan 0 . Dalam perhitungan ini, Persentase kategori diperoleh dari hasil pembagian frekuensi jawaban (jumlah siswa yang memberi jawaban "ya") dikali 100 persen dibagi Jumlah ketersediaan skor jawaban responden (Sudijono, 2012).

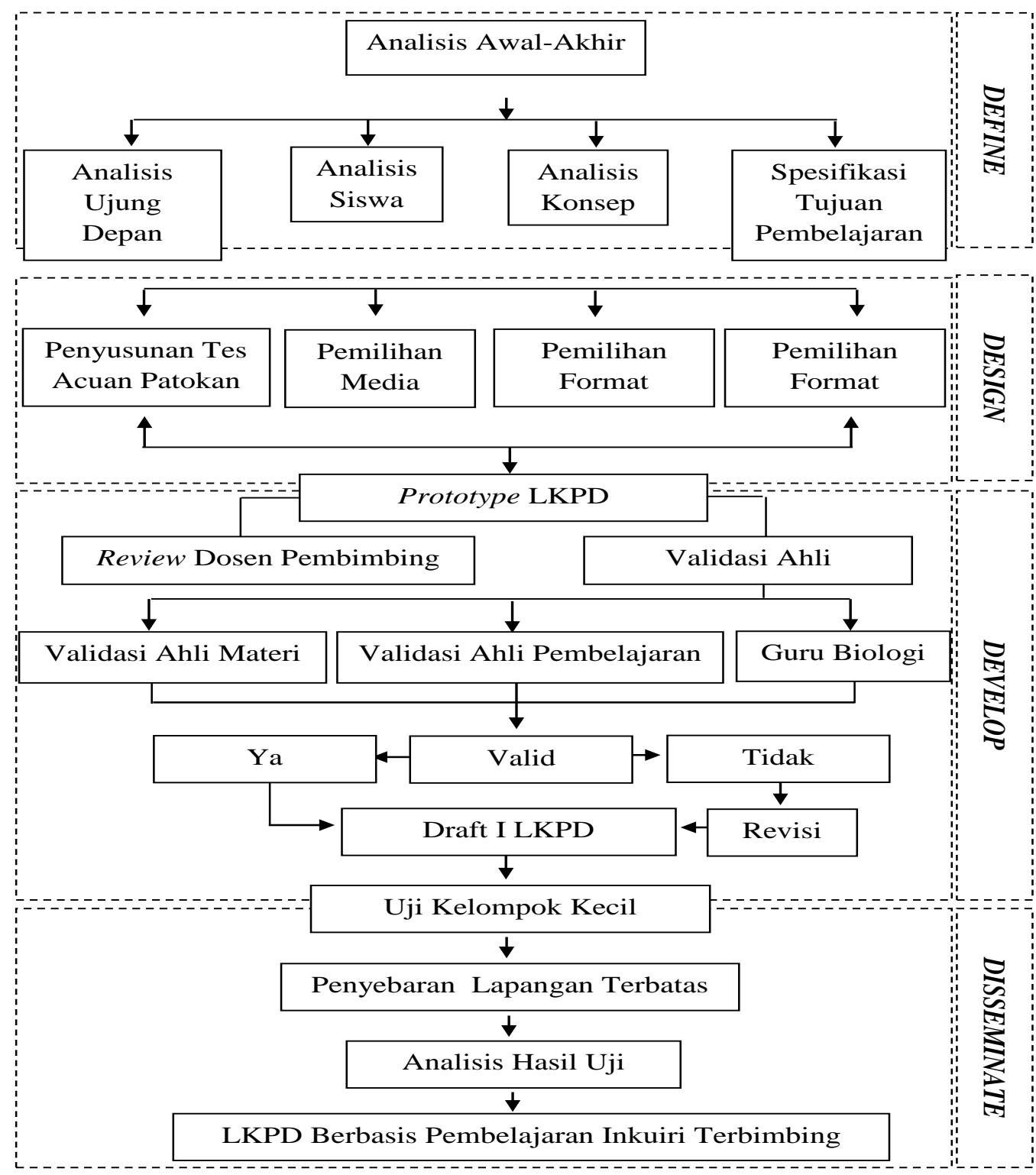

Gambar 1. Modifikasi Model Pengembangan LKPD Berbasis Pembelajaran Inkuiri Terbimbing Dari Thiagarajan.

\section{HASIL DAN PEMBAHASAN}

\section{Hasil Validasi oleh Ahli Materi}

Data hasil validasi oleh ahli materi bertujuan untuk menilai tingkat kelayakan LKPD yang dirancang dinilai dari segi kelayakan isi, kelayakan penyajian, kebahasaan dan kontekstual. Validator ahli materi memberikan skor total 78 dengan persentase sebesar $91,8 \%$ kriteria sangat layak.
Hal-hal yang telah direvisi dari saran ahli adalah sebagai berikut: (1) membaca beberapa sumber untuk mendalami materi; (2) Mencari beberapa contoh soal UN: (3) Membuat peta konsep yang lebih terkonsep; (4) Menggunaan gambar yang lebih menarik dan ilmiah; (5) Menggunakan bahasa yang lebih ilmiah; (6) Memasukkan 1 soal kategori C6 untuk melatih kemampuan berfikir kritis. 


\section{Hasil Validasi oleh Ahli Pembelajaran}

Data hasil validasi oleh ahli materi bertujuan untuk menilai tingkat kelayakan LKPD yang dirancang dinilai dari segi kelayakan isi, alur pembelajaran inkuiri terbimbing, dan kegrafisan. Validator ahli pembelajaran memberikan skor total 75 dengan persentase rata-rata 93,75\% kategori sangat layak.

Hal-hal yang telah direvisi dari saran ahli adalah sebagai berikut: (1) Menggunakan katakata yang lebih menarik dan memotivasi dalam petunjuk pengerjaan LKPD dan; (2) Menggunakan hiasan/ilustrasi yang lebih menarik dan mencerminkan pembelajaran inkuiri terbimbing.

\section{Hasil Penilaian Guru Biologi}

Penilaian diberikan oleh 3 guru Biologi di MAN 1 Medan. Hasil dari penilaian tersebut akan membantu dalam merevisi produk LKPD jika terdapat kekurangan akan hal-hal yang perlu diperbaiki. Aspek yang dinilai oleh guru biologi yaitu tampilan LKPD, kelayakan penyajian LKPD dan kebahasaan. Berdasarkan hasil penilaian dari ketiga guru biologi terhadap produk LKPD berbasis pembelajaran inkuiri terbimbing (guided inquiry learning) diperoleh persentase rata-rata total $87,56 \%$ dengan kategori sangat layak.

\section{Hasil Uji Kelompok Kecil}

Pada uji kelompok kecil yang dilakukan terhadap 20 siswa MAN 1 Medan dihasilkan tanggapan atau respon terhadap LKPD yang dirancang. Respon yang dihasilkan meliputi penilaian dari aspek ketertarikan, penyajian LKPD, komponen pembelajaran berbasis pembelajaran inkuiri terbimbing. Berdasarkan hasil tanggapan siswa terhadap produk LKPD berbasis pembelajaran inkuiri terbimbing (guided inquiry learning) diperoleh persentase rata-rata total $76,47 \%$ dengan kategori baik.

\section{Hasil Uji Lapangan Terbatas}

Pada uji lapangan terbatas dihasilkan data berupa kemampuan berpikir kritis dan hasil belajar siswa yang dilakukan terhadap 36 siswa MAN 1 Medan. Berdasarkan hasil uji lapangan terbatas, diketahui bahwa persentase skor total kemampuan berpikir kritis siswa adalah sebesar $67,33 \%$ dengan kategori cukup baik dan perolehan ketuntasan belajar siswa secara klasikal diperoleh sebesar $86,11 \%$.

LKPD dikatakan valid apabila hasil analisis sesuai dengan kriteria yang telah ditentukan sebelumnya. Seperti yang dijelaskan oleh Arikunto (2013), sebuah LKPD dikatakan memiliki validitas jika hasilnya sesuai dengan kriterium, dalam arti memiliki kesejajaran antara hasil tes dengan kriterium yang telah ditentukan sebelumnya. Dalam penelitian ini, tingkat kevalidan diukur dengan menggunakan rating scale dimana data mentah yang telah diperoleh berupa angka kemudian dikategorikan sesuai dengan persentase yang diperoleh. Skala yang digunakan adalah skala Likert dengan rentang skala 1 sampai 5.

Berdasarkan hasil validasi yang telah dilakukan oleh validator ahli materi, diperoleh nilai 91,8\% dengan kriteria sangat layak. Ahli pembelajaran memberikan nilai 93,75\% dengan kriteria sangat layak. Sedangkan praktisi di lapangan yaitu guru dan siswa memberikan nilai sebagai berikut: guru bidang studi biologi MAN 1 Medan memberikan nilai $87,56 \%$ dengan kriteria sangat layak dan siswa memberikan nilai $76,47 \%$ dengan kriteria sangat baik. Hasil penilaian tersebut menunjukkan bahwa LKPD sangat layak digunakan dalam kegiatan pembelajaran. Sebelum dikatakan sangat layak, dalam proses penilaiannya ada beberapa perbaikan yang harus diperbaiki agar LKPD yang dirancang dinyatakan valid dan dapat dilanjutkan untuk tahap berikutnya. Karena semua aspek penilaian LKPD pada kategori valid maka LKPD dapat digunakan pada tahapan selanjutnya, yaitu uji coba lapangan terbatas untuk melihat kemampuan berpikir kritis siswa dan ketuntasan belajar siswa secara klasikal.

Dari hasil pengujian diperoleh bahwa siswa memiliki kemampuan berpikir kritis sebesar $67,33 \%$ dengan kriteria cukup baik. Kemampuan berpikir kritis siswa dinilai berdasarkan jawaban siswa dalam menyelesaikan langkah-langkah inkuiri pada setiap kegiatannya. Kemampuan berpikir kritis siswa tergolong baik meliputi: a) merumuskan masalah dan b) melakukan pengamatan/percobaan. Namun, ada beberapa indikator keterampilan berpikir kritis siswa tergolong cukup baik, yakni: a) membuat hipotesis, b) menganalisis data dan c) membuat kesimpulan. Berdasarkan data tersebut, diketahui bahwa 
beberapa indikator keterampilan berpikir kritis siswa masih perlu mendapat perbaikan.

Belajar menjadi bermakna bagi siswa apabila mereka mendapat kesempatan untuk mengajukan pertanyaan, melaksanakan penyelidikan, mengumpulkan data, membuat kesimpulan dan berdiskusi. Dengan kata lain siswa terlibat secara langsung dalam pembelajaran aktif dan berpikir tingkat tinggi, yang pada gilirannya akan membimbing/mengarahkan mereka pada pembelajaran berbasis inkuiri ilmiah (Rustaman. 2005). Meskipun guru sudah mulai melibatkan siswa dalam pembelajaran aktif, namun keterampilan berpikir kritis siswa masih tergolong cukup baik disebabkan karena siswa belum terbiasa dengan pembelajaran berbasis inkuiri terbimbing.

Fadillah, dkk (2015) menyatakan bahwa keterampilan berpikir kritis diperlukan dalam upaya untuk mempersiapkan masa depan diri siswa dalam memecahkan masalah, termasuk dalam mengambil keputusan dalam dunia kerja yang akan diadapi siswa kelak dalam permasalahan sehari-hari. Keterampilan ini perlu dilatihkan oleh guru kepada siswa dalam kegiatan pembelajaran mereka di kelas. Pembelajaran biologi dengan metode yang tepat, diharapkan menjadi sarana pengembangan kemampuan berpikir ini, sehingga proses pembelajaran berlangsung optimal. Kardi (2013) dalam Fadillah, dkk (2015) menambahkan bahwa model umum inkuiri adalah strategi mengajar yang dirancang untuk membimbing siswa bagaimana meneliti masalah dan pertanyaan berdasarkan fakta. Keterlibatan siswa di dalam kegiatan inkuiri merupakan salah satu cara yang efektif untuk membantu siswa mengembangkan keterampilan berpikir tingkat tingi dan berpikir kritis.

Data hasil ketuntasan belajar siswa secara klasikal diperoleh pada uji lapangan terbatas. Persentase ketuntasan belajar siswa secara klasikal mencapai $86,11 \%$ dengan kriteria ketuntasan minimal (KKM) sebesar 83. Menurut Dekdikbud (1996) dalam Trianto (2010), suatu kelas dikatakan ketuntasan belajarnya (ketuntasan klasikal) jika dalam kelas tersebut terdapat $\geq 85 \%$ siswa yang telah tuntas belajarnya. Persentase ketuntasan yang dicapai siswa menunjukkan bahwa siswa kelas XI MAN 1 Medan sudah mencapai ketuntasan secara klasikal karena sudah memenuhi standar ketuntasan minimal yang telah ditetapkan sekolah.

Menurut Sanjaya (2006), Pembelajaran inkuiri merupakan pembelajaran yang banyak dianjurkan oleh karena strategi ini memiliki beberapa keunggulan, diantaranya: (1) Pembelajaran inkuiri menekankan pada pengembangan aspek kognitif, afektif, dan psikomotor secara seimbang, sehingga pembelajaran lebih bermakna; (2) Dapat memberikan ruang kepada siswa untuk belajar sesuai dengan gaya belajar mereka; (3) Merupakan strategi yang dianggap sesuai dengan perkembangan psikologi belajar modern yang menganggap belajar adalah proses perubahan tingkah laku berkat adanya pengalaman; (4) Dapat melayani kebutuhan siswa yang memiliki kemampuan diatas rata-rata.

Disamping memiliki keunggulan, pembelajaran inkuiri juga mempunyai kelemahan, diantaranya: (1) Jika pembelajaran inkuiri sebagai strategi pembelajaran, maka akan sulit mengontrol kegiatan dan keberhasilan siswa; (2) Strategi ini sulit dalam merencanakan pembelajaran oleh karena terbentur dengan kebiasaan siswa dalam belajar; (3) Kadang-kadang dalam mengimplementasikannya, memerelukan waktu yang panjang sehingga guru sering sulit menyesuaikannya dengan waktu yang telah ditentukan; (4) Selama kriteria keberhasilan belajar ditentukan oleh kemampuan siswa menguasai materi pelajaran, maka SPI akan sulit diimplementasikan oleh setiap guru (Sanjaya, 2006).

Strategi pembelajaran inkuiri memacu siswa memperoleh dan mendapatkan informasi dengan melakukan observasi dan atau eksperimen untuk mencari pertanyaan atau rumusan masalah dengan bertanya dan mencari tahu (Hasruddin, dkk. 2016). Norhasanah dan Fanani (2016) juga menyatakan bahwa pembelajaran dengan pendekatan penemuan akan membantu pelajar menggunakan proses mental dengan mendalam, membuat penggolongan, membuat dugaan, mengukur, menjelaskan dan menarik kesimpulan. 


\section{KESIMPULAN}

Dari hasil penelitian yang telah dilakukan, dapat diambil kesimpulan sebagai berikut: (1) Tingkat kelayakan Lembar Kegiatan Peserta Didik (LKPD) berbasis pembelajaran inkuiri terbimbing (guided inquiry learning) pada materi sistem ekskresi di kelas XI MAN 1 Medan T.P 2017/2018 berdasarkan penilaian dari ahli materi adalah sangat layak dengan persentase nilai sebesar 91,8\%; (2) Tingkat kelayakan Lembar Kegiatan Peserta Didik (LKPD) berbasis pembelajaran inkuiri terbimbing (guided inquiry learning) pada materi sistem ekskresi di kelas XI MAN 1 Medan T.P 2017/2018 berdasarkan penilaian dari ahli pembelajaran adalah sangat layak dengan persentase nilai sebesar 93,75\%; (3) Tingkat kelayakan Lembar Kegiatan Peserta Didik (LKPD) berbasis pembelajaran inkuiri terbimbing (guided inquiry learning) pada materi sistem ekskresi di kelas XI MAN 1 Medan T.P 2017/2018 berdasarkan penilaian dari guru biologi adalah sangat layak dengan persentase nilai sebesar 87,56\%; (4) Tingkat kelayakan Lembar Kegiatan Peserta Didik (LKPD) berbasis pembelajaran inkuiri terbimbing (guided inquiry learning) pada materi sistem ekskresi di kelas XI MAN 1 Medan T.P 2017/2018 berdasarkan penilaian dari siswa adalah baik dengan persentase nilai sebesar 76,47\%; (5) Tingkat kemampuan berfikir kritis siswa kelas XI MAN 1 Medan T.P 2017/2018 setelah menggunakan Lembar Kegiatan Peserta Didik (LKPD) berbasis pembelajaran inkuiri terbimbing (guided inquiry learning) pada materi sistem ekskresi adalah cukup baik dengan persentase nilai sebesar 67,3\%; (6) Ketuntasan belajar klasikal siswa kelas XI MAN 1 Medan T.P 2017/2018 setelah menggunakan Lembar Kegiatan Peserta Didik (LKPD) berbasis pembelajaran inkuiri terbimbing (guided inquiry learning) pada materi sistem ekskresi adalah tuntas karena sudah memenuhi standar ketuntasan minimal yang telah ditetapkan sekolah dengan persentasi nilai sebesar $86,11 \%$.

\section{DAFTAR PUSTAKA}

Arikunto, S., (2013), Prosedur Penelitian Suatu Pendekatan Praktik, Rineka Cipta, Yogyakarta.

Fadilah, S.I., Kardi, S. dan Supardi, I., (2015), Pengembangan Perangkat Pembelajaran
Biologi Berbasis Inkuiri Materi Sistem Ekskresi Manusia Untuk Melatih Keterampilan Berfikir Kritis Dan Kerjasama Siswa SMA, Pendidikan Sains Pascasarjana Universitas Negeri Surabaya 5 (1): 779-787.

Hadiati, D. dan Yusuf, M., (2016), Perbedaan Hasil Belajar Yang Diajarkan Dengan Model Pembelajaran Problem Based Learning (PBL) Dan Model Pembelajaran Inkuiri Pada Materi Sel Di SMA Negeri 16 Medan T.P 2015/2016, Jurnal Pelita Pendidikan 4 (1): 82-90.

Hasruddin, Erlina, A., dan Mulyana, R., (2016), Pengaruh Strategi Pembelajaran Inkuiri dan Discovery terhadap Kemampuan Berfikir Kritis dan Hasil Belajar Biologi Siswa pada Topik Bioteknologi di MAN 1 Padangsidimpuan, Jurnal Pendidikan Biologi 5 (2): 74-81.

Norhasanah dan Fanani, M., (2016), Penggunaan Lembar Kegiatan Siswa (Hand on Activity) Dalam Pembelajaran Biologi Untuk Menggali Keterampilan Berpikir Kritis Siswa SMA, Nugroho, Proceeding Biology Education Conference 13 (1): 307-311.

Nugroho, S., Suparni dan Sarwanto, (2012), Pembelajaran IPA Dengan Metode Inkuiri Terbimbing Menggunakan Laboratorium Riil Dan Virtuil Ditinjau Dari Kemampuan Memori Dan Gaya Belajar Siswa, Jurnal Inkuiri 1 (3): 235-244.

Permendikbud, (2013), Tentang Kerangka Dasar dan Struktur Kurikulum Sekolah Menengah Atas/Madrasah Aliyah Nomor No. 65 Tahun 2013, Jakarta.

Rehulina, (2015), Pengembangan Lembar Kerja Siswa (LKS) Berbasis Inquiry Untuk Pembelajaran Biologi SMA, Jurnal Pendidikan Biologi 5 (1): 1-9.

Rustaman, N.Y., (2005), Perkembangan Penelitian Inquiry Dalam Pendidikan Sains, Universitas Pendidikan Indonesia, Jakarta.

Sanjaya, W., (2006), Strategi Pembelajaran Pembelajaran Berorientasi Standar Proses Pendidikan, Kencana Prenada Media Group, Jakarta.

Sari, A. dan Lepiyanto, A., (2016), Pengembangan Lembar Kegiatan Peserta Didik (LKPD) Berbasis Scientific Approach Siswa SMA Kelas X Pada Materi Fungi, Jurnal Pendidikan Biologi 7 (1): 41-48 
Sudijono, A., (2012), Pengantar Evaluasi Pendidikan, Raja Grafindo Persada, Jakarta.

Trianto, T., (2010), Mendesain Model Pembelajaran Inovatif-Progresif, Kencana, Jakarta.

Wahyuningsih, F., Saputro, S. dan Mulyani, S., (2014), Pengembangan LKS Berbasis Inkuiri Terbimbing Pada Materi Pokok Hidrolisis Garam Untuk SMA/MA, Jurnal Paedagogia 17 (1): 94-103. 